\title{
HOW RELEVANT IS THE ORIGIN OF HUMAN CAPITAL FOR IMMIGRANT WAGES? EVIDENCE FROM SPAIN*
}

\author{
ESTEBAN SANROMÁ \\ IEB, University of Barcelona \\ RAÚl RAMOS \\ AQR-IREA, University of Barcelona \\ HiPólito SIMÓN \\ IEI, Universidad de Alicante \& IEB
}

Submitted March 2013; Accepted September 2014

\begin{abstract}
The objective of this article is to analyse the role played by the different components of human capital in the wage determination of immigrants in the Spanish labour market. Using microdata from the Encuesta Nacional de Inmigrantes, we find that human capital of immigrants acquired in Spain presents higher returns than human capital obtained in home countries, reflecting the limited international transferability of the latter. This result is reinforced by the strong heterogeneity observed in wage returns to different kinds of human capital across immigrants from different origins and, in particular, by the fact that immigrants with the higher returns to human capital acquired in their home countries are those coming from other developed countries and Latin America, the two regions more similar to Spain in terms of development and/or culture.
\end{abstract}

JEL classification codes: J15, J24, J31, J61.

Key words: Immigration; wages; human capital, assimilation.

\section{Introduction and objectives}

Human capital in its many forms has been considered a key factor in the determination of individual wages and their growth over time (Card 1999; Psacharopoulos and Patrinos 2004). Consistent with this perspective, the analysis of the situation of immigrants within their host countries' labour markets has focused on their human capital as well. The two main empirical results reached from several decades of academic effort regarding wages of immigrantsthe presence of a significant initial wage gap relative to native-born workers and the rapid wage growth from the moment of arrival — can basically be explained by their human capital. Thus, the wage disadvantage experienced by

\footnotetext{
* Esteban Sanromá: IEB, Universitat de Barcelona, Avda. Diagonal 690, 08034 Barcelona (Spain), e-mail: esanroma@ub.edu. Raúl Ramos: AQR-IREA, Universitat de Barcelona, Avda. Diagonal 690, 08034 Barcelona (Spain). -mail: rramos@ub.edu. Hipólito Simón: IEI, Universidad de Alicante \& IEB, Departamento de Análisis Económico Aplicado, Universidad de Alicante, Facultad de Ciencias Económicas y Empresariales Ap.Correos 99 (03080 Alicante, Spain), e-mail: hsimon@ua.es. This study received financial support from research projects ECO2013-41310-R, ECO2013-41022-R, and CSO2011-29943-C03-02. The authors wish to thank the editor and one anonymous referee for useful comments and suggestions. The usual disclaimer applies.
} 
immigrants when they arrive in a new country can generally be attributed to the limited transferability of the human capital they have acquired in their home country. The reason may lie in the lower quality of the educational system there or in a different cultural background. Whatever the case may be, the relevant fact is that newly arrived immigrants lack sufficient human capital for their host country's labour market (Chiswick 1978; Chiswick and Miller 1985, 2009; Friedberg 2000). On the other hand, the explanatory factor behind the rapid growth over time in immigrant wage levels can be found in their accumulation of different types of human capital in the host country, which is particularly significant in the first years of residence in the host country. It is noteworthy that it is this rapid growth in wage levels that generally leads to wage assimilation with the native population (inter alia, Chiswick 1978; Baker and Benjamin 1994; Chiswick and Miller 1995 and Bell 1997).

Concerning the general analysis of immigrant wages in host countries and the role played by human capital as explanatory factor, major advances have been made by differentiating the effect of the different components of human capital. Consequently, studies focusing on immigrants' wage returns to education have shown the relevance of distinguishing between education completed in home and in host countries, given that their wage effects differ significantly (Schaafsma and Sweetman 2001; Bratsberg and Ragan 2002; Ferrer and Riddell 2003). Moreover, their findings suggest that wage returns to education also differ across types of countries of origin and that, in particular, the level of economic development of the countries positively affects the transferability of studies completed there (Bratsberg and Ragan 2002). In addition, analyses that have addressed non-linearity in immigrants' years of schooling show that age and educational level attained could be significant at the time of emigrating (Ferrer, Green and Riddell 2006; Hartog and Zorlu 2009). Similarly, it has been also considered necessary to separate years of experience in the home country from years of experience obtained in the host country, as long as returns to the former are generally zero or at least considerably lower than the latter (Chiswick and Miller 1985; Kossoudji 1989; Friedberg 2000; Schaafsma and Sweetman 2001).

Along the same lines, the recent literature on wage progress in host countries and the process of assimilation also supports the usefulness of breaking down education and experience into the components related to home and host countries (Friedberg 2000; Skuterud and Su 2012; Clark and Lindley 2009). Doing so, the limitations of the first empirical models, in which using the variable "years since immigration" did not allow to distinguish among different types of activities pursued after the immigrant's arrival, can be overcome. An additional important advance in a few recent studies has been to highlight the relevance of effective work experience, given that the 
accumulation of human capital specific to the new country is not necessarily the same if the immigrant holds employment or is jobless (Chiswick, Lee and Miller 2005; Galloway 2008; Skuterud and Su 2012).

We examine the wages of immigrants in the Spanish labour market in order to analyse the role played by the various components of human capital and, in particular, on the relevance of the foreign acquired human capital. Our contribution to the literature is twofold: first, our study provides novel evidence regarding the transferability of human capital for immigrants for different geographic origins in the same labour market; and, second, we provide novel evidence for the Spanish labour market during the recent migration boom. Studying immigration in the Spanish labour market is a matter of great interest, because Spain has become in a relatively short time a country with significant and heterogeneous migration flows in the international context (OECD 2011). Although the economic crisis has changed the dynamics of migration flows, extensive research is still needed to devise immigration strategies and policies to guarantee economic well-being and social stability for a group of workers particularly affected by the current worsening in labor market conditions. In this sense, the factors explaining immigrant wages are of special interest, particularly returns to their endowments of human capital, which is their primary—and, in many cases, only—asset. The recent nature of immigration in Spain, however, has made it difficult to obtain appropriate statistical information, which has in turn limited and conditioned studies on immigration in the Spanish labour market. Consequently, because of the absence of wage data, Amuedo-Dorantes and de la Rica (2007), Fernández and Ortega (2008) and Sanromá, Ramos and Simón (2008) have analysed immigrant assimilation in terms of employment status, occupation, contract type and over-education. In a similar vein, Simón, Sanromá and Ramos (2008) analysed differences in wages structures between native and immigrant workers using microdata drawn from the 2002 Spanish Earnings Structure Survey (Encuesta de Estructura Salarial), which do not include information on the time of arrival in Spain (and consequently on education and work experience acquired in the home country). Finally, Izquierdo, Lacuesta and Vegas (2009) have analysed assimilation of immigrants using the Continuous Sample of Working Lives (Muestra Continua de Vidas Laborales) which, in addition to lacking the year of arrival in Spain, required the use of Social Security contribution figures as a proxy for wage levels.

In this article, we overcome earlier limitations by making use of microdata from the Spanish National Immigrant Survey 2007 (Encuesta Nacional de Inmigrantes 2007), which was conducted by the Spanish National Statistics Institute between 2006 and 2007. The ENI collected a wide range of statistical information about immigrants, including their actual wages. Moreover, it allows to distinguish, following a similar approach to recent 
literature, between education completed in home and host countries and to break down years of experience between home and host countries as well. In addition, the ENI enables a good approximation of effective work experience in Spain to be calculated, as well as years without employment. Lastly, it also provides information on immigrants' home countries, which facilitates the estimation of returns to human capital by economically different areas of origin.

The National Immigrant Survey comprises a single cross-section, which rules out longitudinal analysis. It also impedes the construction of a pseudo-panel combining information from different cross-sections, a highly useful approach in the literature since the contribution of Borjas (1985). Working with a cross-section can lead to bias in the estimation of returns to human capital gained in Spain. The bias could result from three different causes: changes in the composition or quality of the immigrants arriving at different points in time (Borjas 1985, 1995); the effect of the economic cycle on the wages of individuals entering the labour market at different times (Aslund and Rooth 2007); and the existence of return migration (or onward migration to a third country) (Constant and Massey 2003; Dustmann and Weis 2007; Lubotsky 2007). To minimise the problems arising from working with a single cross-section, the empirical analyses have been conducted on immigrants arrived in Spain between 1997 and 2007. The selection of this specific group of immigrants is intended to address the three problems set out above. Firstly, immigrants prior to 1997 mostly came from developed countries or from a number of relatively advanced Latin American countries, while the bulk of the immigrant population arriving subsequently have come from Latin America (basically the Andean countries), Eastern Europe and Africa (Reher et al. 2008). Working with entire ENI sample would have involved a change in the quality and composition of the immigrants arriving at different points in time, while the selection actually used considerably reduces this problem. However, it is worth mentioning that between 1994 and 2007, immigrants from Latin America and the Rest of the World have decreased their relative share in Spain in favour of immigrants from Eastern Europe that have nearly doubled during this period. However, this change in immigrants' characteristics was relatively small as it has been only after the beginning of the crisis in 2008 that the characteristics of immigrants coming to Spain has substantially changed (Fernandez-Huertas 2014). Moreover, in order to control the make-up of the immigrant population more effectively separate estimations have been performed by region of origin. In a similar vein, in the interests of greater homogeneity, immigrants with Spanish nationality from birth have been excluded. Secondly, the period 1997-2007 is a homogeneous period of sustained growth and intense job creation, with the consequence of minimising the persistent effects of the economic 
cycle on wages. Lastly, it would seem reasonable to argue that return migration is not quantitatively significant when working solely with a period of economic expansion. The business cycle change observed in 2008 does appear to have resulted in rising levels of return migration (although government measures encouraging return migration is another factor at work). As the ENI was conducted in late 2006 and early 2007, the data should not be affected by either the cyclical change or government intervention ${ }^{1}$.

The results show significant differences in returns to distinct components of human capital of immigrants. Of particular importance is where the human capital was acquired. In general, returns to studies completed in Spain exceed returns to studies completed in the home country, except in the case of immigrants from developed countries. In addition, wage progress occurs for immigrants as a function of the length of their stay in Spain, because experience gained in Spain is more valuable than experience abroad, which has a limited transferability (again, except in the case of immigrants from developed countries). In general, the analysis shows appreciable differences in returns to human capital and the pace of wage progress as a function of the area from which immigrants come. The differences are significant when comparing immigrants from developed and developing countries, but also when comparing the different geographic areas to which the developing countries belong. The differences appear to depend on their economic and cultural distance from Spain which reinforces the conclusion of the limited international transferability of the human capital obtained by immigrants in home countries.

The rest of the article is structured in three parts. Below, the next section sets out the principal characteristics of the database used in the empirical analysis. It also describes how the principal variables of interest have been constructed in the study. Then, we describe the methodology applied and we show the results obtained. Lastly, we summarise the main conclusions of the article.

\section{The National Immigrant Survey 2007}

The National Immigrant Survey (hereafter, ENI) is a survey prepared by the Spanish National Statistics Institute in order to obtain detailed information on the international nature of immigration in Spain, supplementing information gathered from regular sources of data (such as the Padrón Municipal, the Encuesta de Variaciones Residenciales, the Encuesta de Población Activa o the Censo de población), which provide partial information on the

\footnotetext{
${ }^{1}$ It should be noted, however, that this solution is not optimal. As a result, the results presented in the article must be interpreted with caution.
} 
characteristics of immigration. The scope of the ENI covers all of the national territory of Spain and the data collection was conducted between November 2006 and February 2007 based on the Padrón Municipal, using the week prior to the interview as the reference period ${ }^{2}$. The original survey sample comprises approximately 15,500 individuals.

The ENI provides detailed information on the sociodemographic characteristics of immigrants (e.g., age, sex, nationality, country of birth, marital status, legal status, knowledge of languages and year of arrival in Spain) and on their current work situation (as well as information on the characteristics of their first job in Spain, although to a lesser extent than their current job). The range of questions on immigration covered by the survey is very wide comprising, among others, immigrant household structure and accommodation characteristics; family and social networks; previous situation in their home countries and their current relationship to those countries, and various aspects of their migration experience.

The ENI defines immigrants as any individuals born abroad (regardless of whether they have Spanish nationality or not) who at the time of doing the interview had reached at least 16 years of age and had resided in a home for a year or longer (or, alternatively, in the case of individuals with less than one year's residence in Spain, had the intention to remain there for at least a year). The only exception is individuals born outside Spain who have possessed Spanish nationality from birth, but had not reached two years of age by the time of arrival in Spain. In that case, Spain was considered as their country of origin. This definition of immigrant meant, among other circumstances, that individuals born abroad but with Spanish nationality are considered immigrants, while foreign nationals born in Spain are not. Hence, this approach excludes individuals born in Spain of foreign immigrants, even if their nationality is not Spanish. It also excludes Spanish emigrants who have returned to Spain ${ }^{3}$. We have also excluded immigrants arriving to Spain with less than 12 years old.

Wages received by immigrants are expressed in monthly terms and correspond to the pay received in their principal job in net terms (i.e., after deductions, contributions and other related payments), including the proportional monthly part corresponding to extraordinary payments and other extraordinary income received on a

\footnotetext{
${ }^{2}$ More detailed information on the contents of the ENI, the sample design and the data collection procedure used can be consulted in the web page of the National Statistics Institute (www.ine.es).

${ }^{3}$ Using a definition based on country of birth contrasts with the alternative definition based on nationality, which has generally been used in previous studies on immigration and its effects on the Spanish labour market (see, for example, Amuedo-Dorantes and de la Rica, 2007; AmuedoDorantes and de la Rica, 2011, Carrasco, Jimeno and Ortega, 2008; González and Ortega, 2011, and Simón, Sanromá and Ramos, 2008).
} 
regular basis ${ }^{4,5}$. Hourly wages have been calculated combining this information with usual weekly working hours multiplied by 4.2 (i.e., the average number of weeks in a month).

As previously emphasised, the central aspect examined in this research is how different forms of human capital affect immigrant wages. This requires differentiating between education and work experience and knowing whether these types of human capital have been acquired in the immigrants' home countries or in Spain. As the ENI lacks exact information on the age at which immigrants have finished their studies, the breakdown of human capital into foreign and domestic components is based on a standard approach in the literature. Therefore, after measuring education in years, the approximation assumes that the period of education has been pursued continuously from the first year of entry into the school system at six years of age until the individual's studies reach their conclusion. This makes it possible in the final analysis to approximate the age at which studies are concluded as the total number of years in education plus $\operatorname{six}^{6}$. Potential work experience corresponds to the difference between the individual's age and the age at which studies were concluded. In addition, knowing the year of arrival in Spain makes it possible to differentiate which portion of an immigrant's human capital has been acquired in the home country and in Spain, in the case of both education and work experience. Moreover, potential work experience in the Spanish labour market can be differentiated into effective work experience and years without employment. With respect to the labour market in the home country, the information contained in the ENI is insufficient to calculate effective work experience. For this reason, only a variable that measures whether the immigrant has worked in the home country at some time prior to emigrating to Spain (and consequently whether he has effective work experience prior to arrival) has been employed.

In order to break down the information by area of origin, immigrants have been grouped by country of birth, distinguishing between developed and developing countries. Developed countries include the EU-15 countries, Norway, Switzerland, Iceland, Cyprus, Malta, the small European principalities, the United States, Canada, Israel,

\footnotetext{
${ }^{4}$ Even when wages correspond to the principal job, a dummy variable has been introduced into the empirical estimations, which measures whether the individual has more than one job or not. The purpose is to control for any possible effect on wages. With a few exceptions, the variable tends to have a negative coefficient and to be statistically significant.

${ }^{5}$ If surveyed individuals chose not to provide the exact value of their wages during the ENI interview, they were given the option to identify their wages against a list of set wage bands. Individuals providing alternative information of this sort (around a $15 \%$ of full sample) have not been considered in our analysis. However, as a robustness check, we have estimated an interval regression for monthly wages with all individuals. Results, which are available from the authors on request, are very close to the ones shown here.

${ }^{6}$ In the absence of information on the exact age of finishing studies, this approach reflects a standard approximation in the literature (see, for example, Friedberg 2000). In order to interpret the results, however, it is necessary to bear in mind that this figure tends to overestimate (underestimate) the years of study in the home country (host country). Skuterud and Su (2012) provide a thorough review of the various approaches used to calculate foreign and domestic human capital and determine their influence on empirical estimations. They conclude that there is no significant difference between the results obtained when applying the different approaches.
} 
Japan, Australia and New Zealand. All other countries have been considered developing, distinguishing three main areas: Latin America, Eastern Europe and the rest of the world.

Other variables employed in the empirical analysis include sex, marital status, controls by region and the number of children in the household In addition, a variable has been devised to capture immigrants' legal status, reflecting whether or not they have documents to become legally contracted employees under current Spanish law. The variable is dichotomous and reflects whether immigrants state that they have any of the following documents: permanent residency authorisation; temporary residency authorisation ${ }^{7}$; EU residence permit (except in the case of Romanian and Bulgarian workers who, despite being EU citizens, could not become legally contracted workers in Spain temporarily at the time of the ENI); refugee status or asylum application. This category also includes immigrants whose nationality is Spanish, from other EU member state (excluding Bulgaria and Romania) or from non-EU members of the European Free Trade Association (i.e., Liechtenstein, Iceland, Switzerland and Norway). Alternatively, immigrants not considered to have documentation to work legally as contracted employees include Romanian and Bulgarian residents; immigrants with student visas; immigrants who have residency applications pending or have not yet submitted their applications; immigrants who state that they have none of the documents listed above and immigrants who respond that they do not know which documents they possess.

Observations have been excluded from the original sample for individuals with incomplete information concerning the variables of interest; individual who are under 16 or over 65 years of age; individuals with net monthly wages below 200 euros or usual weekly working hours less than 10 hours or more than 90 . The final sample also excludes immigrants with Spanish nationality at birth and immigrants who arrived before 1997 . The final sample comprises 4,143 immigrant employees.

Table A.1 in the appendix contains the descriptive factors for the ENI sample. The characteristics of the immigrants covered by the survey generally fit the profile characterising recent immigration to Spain. Without intending to be exhaustive ${ }^{8}$, the immigrants in the sample are basically from developing countries (93.3\%), particularly Latin America (53.7\%) and Eastern Europe (27.1\%). They are mostly men (53.2\%) and the average age is approximately 34 years old. The immigrants in the sample also acquired the bulk of their human capital in their

\footnotetext{
${ }^{7}$ In the case of temporary residency authorisation, the immigrant does not necessarily receive a work permit in Spain. The immigrant's application and the issuing of a work permit by the authorities are discretionary. However, the overall results of the empirical analysis do not show significant variations, regardless of which of the two categories of the dichotomous variable on legal status is assigned to immigrants in this situation. Detailed results are available from the author on request.

${ }^{8}$ For a more detailed description of the immigrants in the ENI, see the report Informe Encuesta Nacional de Inmigrantes (ENI-2007), which is available in the web page of the National Statistics Institute (www.ine.es).
} 
home country (10.95 of their 11.1 years of education, on average, correspond to their home countries, and in the case of potential work experience, 12.61 of the 16.81 years on average). For the most part, their length of stay in Spain (4.33 years on average) leads to their accumulating potential work experience (4.20 years of which 3.55 correspond to effective work experience and 0.64 reflects periods of unemployment), while their accumulation of education is very limited (only 0.14 years). This largely reflects the low percentage of immigrants who have completed studies in Spain. Immigrants who have studied in Spain make up 5.5\% of the total sample. They are typically younger and have arrived in Spain at an earlier age than other immigrants. They have slightly higher hourly wages (1.72 euros per hour). They come largely from developed countries and Latin America. They have lower levels of work experience in both their home countries and host countries, and they possess high endowments of education, averaging 12.2 years of education, of which 2.59 correspond to years of study in Spain. Moreover, the vast majority of the immigrants have legal status to work $(87.0 \%)$ and previous work experience in their home country $(86.1 \%)$.

In addition, the overall group of immigrants shows a strong heterogeneity in their characteristics as a function of area of origin. For example, while the average hourly net salary is 1.671 euros per hour, it reaches 1.936 euros per hour for immigrants from developed countries and 1.651euros per hour for immigrants from developing countries. Along the same lines, notable differences can be observed in educational endowments (with comparatively lower endowments for immigrants from the rest of the world) and in legal status (with a less stable situation for immigrants from Eastern Europe).

\section{Empirical evidence}

The first model used in this study to analyse immigrants' economic progress is a semi-logarithmic Mincerian wage equation with the form:

$w_{i}=\alpha+\delta \cdot y s m_{i}+\beta_{1} \cdot \operatorname{sch}_{i}+\beta_{2} \cdot \operatorname{potexp}_{i}^{f}+\beta_{3} \cdot \operatorname{potexp}_{i}^{f^{2}}+\gamma \cdot X_{i}+\varepsilon_{i}$

where $w_{i}$ corresponds to the logarithm or hourly wages for individual $i$, the variable $y s m_{i}$ indicates the number of years since arrival in the host country, the variable $s c h_{i}$ represents the number of years of studies completed and the 
variable $\operatorname{potexp}_{i}$ denotes the number of years potential experience in the home country which is squared, as is usual in the literature. $X_{i}$ is a vector that represents other individual characteristics which have an influence on wages, while $\varepsilon_{i}$ is a random error term.

Chiswick, Lee and Miller (2005) have estimated equation (1) for a sample of immigrants to Australia. Their results show a significant, positive effect on wages from the amount of time that has passed since arrival in Australia. The significant economic progress achieved by immigrants in their study is consistent with the hypothesis of wage assimilation. This specification has also been used in various other studies on immigrant wages (see, for example, Accetturo and Infante 2010).

Table 1 shows the result of estimating equation on the immigrant sample described in the previous section, treating the logarithm of monthly wages as the endogenous variable. As can be seen in the first column of Table 1, the results obtained regarding human capital variables ${ }^{9}$ show that the years of residence in Spain have a positive and significant effect on immigrant wages. More specifically, each year of Spanish residence gives rise to a wage hike of $1.7 \%$, an increase that could be interpreted as evidence supporting the notion of economic progress for immigrants: a longer period of residence in Spain implies an improvement with respect to the initial wages received. Although the returns are diminishing, a year of potential experience in the home country also has a positive, but modest, effect on immigrant salaries.

The results from estimating equation (1) also show that studies have a positive and significant effect on immigrant wages. More specifically, each year of completed studies results in a hourly wage increment of $1.5 \%$. In comparative terms, the figure is notably lower than returns to studies for native workers, which according to estimations obtained from the Earnings Structure Survey 2006 are approximately $4 \%^{10}$. As indicated by Chiswick (1978), Chiswick and Miller (1985) and Friedberg (2000), among many others, the lower returns to completed

\footnotetext{
9 Another controls included in the regression are gender, marital status, geographic area of birth, legal status, monthly working hours (in logarithms), if the immigrant holds more than one job, if he/she has provided wage information according to predetermined bands and region of residence. The complete results for all estimations presented in the article are available from the authors on request.

${ }^{10}$ Given the lack of recent empirical literature on the returns to studies in Spain, the estimation mentioned above has been obtained by using the Earnings Structure Survey 2006 (EES-2006) and with similar controls to the ones included into the specification based on the ENI-2007. Caution must be exercised in making comparisons as the two surveys reflect statistical operations with distinct purposes and methodologies. For example, the ENI-2007 is a household survey, while the EES-2006 is a company survey gathering data on employees. In addition, the wage concepts used in the two surveys differ. While the ENI-2007 provides information on net wages, the EES-2006 gives information on gross wages. Nonetheless, the estimations of returns to years of study are very similar for immigrants in both cases: $1.8 \%$ according to the ENI-2007 and $2.0 \%$ according to the EES-2006.
} 
studies for immigrants could be explained by the lower (real or perceived) quality of immigrants' studies or their imperfect transferability ${ }^{11}$.

\section{$\{\{$ Place Table 1 about here $\}\}$}

A final issue to emphasise is that the estimation of the model has taken into account the possible existence of bias in employment selection. As a result, the two-stage procedure proposed by Heckman has been applied. The results obtained after applying the first stage of the procedure are shown in Table A.2 in the appendix. Because of issues of identification, it is advisable to include at least one explanatory variable that appears in the selection equation but does not appear in the wage equation. In other words, we need a variable that affects the probability of being in work, but not the salary. We have used the number of children living in the household, as it can affect the decision to participate in the labour market but it does not affect wages. In particular, immigrants can decide to participate in the labour market depending on how many children they have in charge but we do not expect employers to consider this variable when setting their wages. Heckman's lambda (obtained from previous results as the inverse Mills ratio) has been introduced as another explanatory variable in equation (1). As shown in Table A.2 in the appendix, this variable is only significant for the full sample and for immigrants coming from Latin America. For the rest of models, Heckman's lambda is not statistically significant at the usual level. This is a common result in the immigration literature and could be explained by the liquidity restrictions of recently arrived immigrants, leading them to accept available employment without being able to exercise choice (see, for example, Friedberg 2000) and, in the particular case of Spain by the very high activity rate of immigrants that, contrary to what is observed in other European countries, exceeds that of natives both for males and females (De la Rica et al. 2014).

Given the importance of human capital in the explanation of immigrant wages and wage progress, the remainder of the article explores this central aspect in greater depth. A key question that could affect the interpretation of the results associated with the variables related to human capital in equation (1) is the presence of a close relationship between immigrants' years of residence in Spain, their years of study and their years of potential experience. More specifically, as indicated by Borjas (1999), Friedberg (2000) and more recently Skuterud and Su

\footnotetext{
${ }^{11}$ The results obtained from the remaining controls, which are shown in Table A.3, reflect what has typically been found in the literature. There is a favourable wage differential for men in relation to women and there is a wage premium for married immigrants. In addition, wage differences are significant by area of origin as a function of the economic and cultural distance of each area from Spain. There is also a wage penalty for immigrants who work without the necessary legal documentation that could be related to the characteristics of unskilled agricultural and construction jobs they probably develop or to their lower bargaining power.
} 
(2012), the equation is a restricted specification of a broader model that break downs returns to studies and experience according to whether they have been acquired in the home or host countries. The coefficient $\delta$ in model (1) captures the effect of human capital investment in the host country (in this case, Spain), whereas the coefficients associated with years of study and potential experience are affected by the relative composition of human capital in home and host countries. For this reason, it is useful to expand equation (1) as follows:

$$
w_{i}=\alpha+\beta_{1}^{h} \cdot \operatorname{sch}_{i}^{h}+\beta_{1}^{f} \cdot \operatorname{sch}_{i}^{f}+\beta_{2}^{h} \cdot \operatorname{potexp}_{i}^{h}+\beta_{3}^{h} \cdot\left(\operatorname{potexp}_{i}^{h}\right)^{2}+\beta_{2}^{f} \cdot \operatorname{potexp}_{i}^{f}+\beta_{3}^{f} \cdot\left(\operatorname{potexp}_{i}^{f}\right)^{2}+\gamma \cdot X_{i}+\varepsilon_{i}
$$

where the superscript $h$ refers to human capital of any kind acquired in the host country and the superscript $f$ refers to human capital acquired in the home country.

The second column of Table 1 represents the results from estimating equation (2). Based on these estimations, the marginal returns to a year of study in Spain $(3.8 \%)$ are higher than the marginal returns to a year of study in the home country $(1.5 \%)$, and the difference between the two coefficients is statistically significant at $5 \%$. Notably, immigrants' marginal returns to studies completed in Spain are relatively much closer to the $4 \%$ estimated for native workers using microdata in the EES-2006 (see footnote 10). In any case, the lower returns to formal education abroad indicates that the studies completed by immigrants in their home countries have limited transferability to the Spanish labour market. This conclusion is consistent with previous work by Sanromá, Ramos and Simón (2008). The returns to a year of potential experience in Spain are 1.4\%, which would support the existence of wage progress.

Potential experience in the home country has a marginal return of $0.7 \%$ in the Spanish labour market. This figure is lower than returns to experience accumulated in Spain, which supports the notion that the transferability of job experience obtained in the home country is limited with respect to the Spanish labour market. Nevertheless, this result can be seen as favourable in light of contrasting evidence obtained in countries like Israel (Friedberg, 2000), Canada (Schaafsma and Sweetman, 2001) and the United States (Kossoudji, 1989), which points to zero or near zero returns to experience acquired in the home country.

Other recent studies such as Skuterud and $\mathrm{Su}$ (2012) have pointed to the value of also distinguishing between effective and potential experience. As indicated previously, the availability of information in the ENI on immigrant work histories after their arrival in Spain makes it possible to break down years of potential experience in 
Spain into years of effective experience $\left(e f f e x p^{h}\right)$ and years of unemployment and inactivity $\left(u n e m p^{h}\right)$. In addition, it provides information on whether an immigrant has been employed in the home country, permitting the introduction of a dummy variable $\left(j o b^{f}\right)$ to try to represent this effect on wages. In this way, the empirical model can be expanded to reflect the additional breakdown:

$$
\begin{aligned}
w_{i}= & \alpha+\beta_{1}^{h} \cdot \operatorname{sch}_{i}^{h}+\beta_{1}^{f} \cdot \operatorname{sch}_{i}^{f}+\beta_{2}^{h} \cdot \operatorname{effexp}_{i}^{h}+\beta_{3}^{h} \cdot\left(\operatorname{effexp}_{i}^{h}\right)^{2}+\beta_{4}^{h} \cdot \text { unemp }_{i}^{h}+ \\
& +\beta_{2}^{f} \cdot \operatorname{potexp}_{i}^{f}+\beta_{3}^{f} \cdot\left(\operatorname{potexp}_{i}^{f}\right)^{2}+\beta_{4}^{f} \cdot \operatorname{job}_{i}^{f}+\gamma \cdot X_{i}+\varepsilon_{i}
\end{aligned}
$$

The third column of Table 1 shows the results from estimating this equation. The first new contribution of this estimation is that it breaks down the effect of years actually worked in Spain from years of unemployment or inactivity. The first result to highlight in this sense is that returns to effective experience in Spain seem to be greater than returns to potential experience: $2.3 \%$ and $1.4 \%$, respectively, although the difference between the two is not statistically significant at the usual levels. The result would seem to suggest that the wage improvement experienced by immigrants during their period of stay in Spain is largely associated with working and that this is basically the factor which enables them to accumulate knowledge and develop skills that are useful and adapted to the Spanish labour market. Periods of unemployment or inactivity in Spain do not appear to have any statistically significant impact on immigrant wages. That would seem to indicate that skills acquisition and the development of social relationships take place most prominently in the working environment. Although the sign of this variable is negative and not statistically significant at the conventional levels, it does not seem to reflect a wage penalty, which contrasts with what might be expected from the evidence obtained for other countries (Bratsberg, Barth and Raaum 2006). One possible explanation for this finding is that the obsolescence effect may be minimal because the periods of employment involved are generally short as a result of the very high employee turnover in the Spanish labour market ${ }^{12}$, the intensity with which immigrants seek employment and the period of intense hiring occurring during the timeframe of this study.

The second difference between this model and the previous model is the presence of a dummy variable to reflect whether immigrants have held employment in their home countries. The variable is statistically significant at conventional levels, clearly showing that immigrants with work experience in their home country obtain an

\footnotetext{
12 According to Eurostat Labour Force Survey, the average value of the long term unemployment in percentage of active population in the European Union (EU-28) from 2002 to 2007 was 3.9\% while in Spain it was 2.6\%. No data is available for the EU-28 from 1997 to 2001.
} 
additional hourly wage increment of $4 \%$. The existence of a wage premium indicates higher productivity as a result of effective experience gained in the home country, but its limited magnitude draws attention again to the limited transferability of most skills acquired in settings other than the Spanish labour market.

With respect to education, the third model offers a result similar to the previous model. Returns to schooling completed in Spain (4.2\%) are higher than returns to schooling completed in the home country (1.4\%), and the difference is statistically significant at conventional levels.

One additional aspect that has been scarcely analysed in the literature is the existence of wage differences and other work-related results among immigrants as a function of their geographic areas of origin. In order to evaluate whether these differences are also related to distinct returns to the various components of human capital, equation (3) has been estimated separately according to immigrant's areas of origin. Developed and developing economies have been distinguished. Within the category of developing economies, a further breakdown has distinguished among immigrants from Latin America, Eastern Europe and the rest of the world, which are the only three categories with a sufficient sample size. The results appear in Table 2.

The results for immigrants from developed countries show high returns to studies, both for studies completed in Spain (4.0\%) and studies completed in the home country (roughly 5.6\%). These figures, particularly the latter one, are slightly higher than the figure obtained for natives from estimations based on the EES-2006 data (see footnote 10). The evidence reveals a very high transferability of studies completed in developed countries in Western Europe and North America and significant returns to studies completed in Spain. For this group of immigrants, however, a statistically significant positive effect is not observed from effective experience acquired in the Spanish labour market. Nor is there a clear wage penalty as a result of periods of unemployment or inactivity. The result is consistent with the fact that returns to studies in the home country are higher for this group than for natives. Indeed, Simón, Sanromá and Ramos (2008) have found that the wage gap between natives and immigrants from developed economies is favourable to the immigrant group. Therefore, it seems reasonable to expect that their economic progress would not occur or would be less important than for other groups. This result is not new in the literature, but is rather known as "dis-assimilation" or "negative assimilation". For example, Chiswick and Miller (2011) have found that the situation of immigrants from English-speaking countries who emigrate to the United States actually declines over time with respect to their situation on arrival. Bell (1997), Dustman et al. (2003) and Clark and Lindley (2009) have obtained similar evidence for white immigrants to the United Kingdom. Lastly, 
experience accumulated in the home country, by contrast, presents significant positive returns, clearly supporting the complete transferability of such experience to the Spanish labour market, although no differences are detected as a result of having held employment in the home country.

The results for immigrants from developing countries show a positive wage effect from years of study in both home and host countries, as well as from effective experience in Spain and potential experience in the home country. However, returns to each component of human capital are distinct in the Spanish labour market. Specifically, returns to studies completed in Spain (4.0\%) are much higher than returns to studies pursued in the home country $(1.2 \%)$. The low marginal returns to studies completed in developing countries reflect their lower transferability. The same outcome appears when comparing experience gained in the home country with (effective) experience acquired in Spain: a year of work in Spain results in greater wage returns than a year of experience gained at home. Nevertheless, having held employment in their home country is related to immigrants earning wages which are $3.9 \%$ higher within the Spanish labour market.

The results for the three geographic groupings of developing countries clearly show that the marginal returns to studies completed in Spain are higher than returns to studies pursued at home, revealing their limited transferability. In comparative terms, estimated returns to schooling completed in Spain are greater for immigrants from Latin America (4.6\%) than for immigrants from Eastern Europe (3.9\%) and the rest of the world (4.4\%). Exactly the same result arises with respect to returns to schooling completed in the home country. For immigrants from the rest of the world, these returns are even lower than for the rest of regions. Some of the possible explanations for this result could be that the vast majority of Latin American immigrants speak Spanish and that the cultural distance is smaller for immigrants from Easter Europe than for immigrants from the rest of the world. Equally, the gap could reflect the limiting or determinant effect that low-quality studies in the home country could have on the ability of immigrants from the rest of world to benefit effectively from any studies subsequently completed in Spain.

\section{$\{\{$ Place Table 2 about here $\}\}$}

With respect to work experience gained in the home country, a positive wage effect is found only for Latin American immigrants and not for immigrants from Eastern Europe or the rest of the world. In addition, the fact of 
having actually worked in the home country is only related to higher wages (6.2\%) in the case of Latin American immigrants. As already noted, it is common in the literature to find zero returns to experience gained in the home country—both effective and potential—in the case of immigrants from developing countries. Zero transferability is also a common result. The economic, technological, cultural and linguistic distance between home and host countries translates into knowledge and skills that do not match the requirements of a developed country's labour market, the Spanish economy in this case. The explanation could also lie at least partly in the differing levels of Spanish mastery seen when comparing immigrants from Latin America, who experience limited but positive returns, and immigrants from other developing countries. In any event, the result has already been highlighted in previous studies (e.g., Sanromá, Ramos and Simón 2008).

Effective labour experience obtained in Spain only presents positive and significant marginal returns for immigrants from Latin America. By contrast, effective experience in Spain is not statistically different from zero for the remaining immigrants. Fernández and Ortega (2008) have already obtained similar evidence of the absence of assimilation in the levels of over-education for immigrants not coming from Latin America, so it is not surprising to find no wage progress over time for this group as they gain experience after arrival in Spain.

Last, we have also carried out several robustness checks to test the validity of the results. In particular, and in order to check the robustness of the results to the assumptions behind our decomposition of human capital according to the country where it has been acquired, we have estimated alternative specifications including information about the schooling levels finished in Spain (instead of years). The obtained results are consistent with the ones presented here showing the differential effect of foreign and host country human capital and are shown in Table A.4. Moreover, we have also checked the robustness of our conclusions when working with different samples (immigrants with legal status; with only one job; without coming from third countries). Table A.5 in the appendix summarises the obtained results, which are not substantially different to the ones discussed above.

\section{Conclusions}

Our objective was to analyse returns to human capital for recent immigrants to Spain, distinguishing where each component has been acquired, a totally new approach for the Spanish economy and only available for a very limited set of countries. For this purpose, we have used the wide range of recently availably statistical information provided 
by the National Immigrant Survey conducted by the Spanish National Statistics Office. The detailed information in this survey allows breaking down education and experience completed in home and host countries, additionally breaking down immigrant work experience obtained in Spain into effective experience and years without employment and identifying effective work experience obtained in immigrants' home countries. Moreover, and taking into account the heterogeneity in the geographical origin of immigrants coming to Spain during the last economic boom, we have provided novel evidence on the different transferability of human capital acquired abroad in a particular labour market. Consequently, using this dataset we have conducted an in-depth analysis of the influence which distinct types of human capital, both foreign and domestic in origin, have on immigrant wages.

The results obtained support the conclusion that returns to schooling years completed in Spain are clearly higher than returns to schooling years completed in the home country, reaching a level similar to the returns estimated for natives from the microdata collected in the Earnings Structure Survey 2006. Lower returns for formal education abroad indicate that its transferability to the Spanish labour market is limited for recent immigrants.

Positive returns to potential experience in Spain support the existence of strong wage progress, while potential experience acquired by immigrants in their home country presents marginal returns that are clearly lower, reaffirming the limited transferability of human capital among countries at different levels of economic development. Having work experience in the home country, however, does lead to higher wages once in the host labour market. Returns to effective experience in Spain would appear to be higher than returns to potential experience, suggesting that wage progress for immigrants after their arrival in Spain is associated with employment. By contrast, periods of unemployment or searching for work have no positive impact on immigrant wages.

The results for immigrants from developed countries show higher returns to education, which are practically equal whether it has been pursued in Spain or at home. By contrast, their wages do not improve with the accumulation of experience in Spain, which is consistent with the existence of the phenomenon of "negative assimilation" uncovered in a number of studies conducted for other economies. The results for immigrants from developing countries show an effect from the different components of their human capital which is always positive but unequal. For example, returns to studies completed in Spain are much higher than returns to studies in their home country. Similarly, effective experience acquired in Spain is more valuable than experience in the home country. Having held employment in the home country carries a limited wage premium. 
In comparative terms, the evidence suggests that returns to studies in Spain and returns to studies in the home country are both higher for immigrants from Latin America and Eastern Europe than for immigrants from the rest of the world. Work experience at home — both potential and effective — only has a positive wage effect for immigrants from Latin America, indicating limited but positive transferability. Effective work experience in Spain only presents positive marginal returns for immigrants from Latin America. The high coefficient value shows the possibility that a process of wage assimilation could exist for this group of immigrants. By contrast, there is no evidence of wage progress for the other groups of immigrants.

\section{References}

Accetturo, Antonio, and Luigi Infante. 2010. Inmigrant Earnings in the Italian Labour Market. Giornale degli Economisti, GDE (Giornale degli Economisti e Annali di Economia) 69(1): 1-28.

Amuedo-Dorantes, Catalina, and Sara de la Rica. 2007. Labour Market Assimilation of Recent Immigrants in Spain. British Journal of Industrial Relations 45(2): 257-284.

-----. 2011. Complements or substitutes? Task specialization by gender and nativity in Spain. Labour Economics 18(5): 697-707.

Aslund, Olof and Dan-Olof Rooth. 2007. Do when and where matter? Initial Labour Market Conditions and Immigrant Earnings. The Economic Journal 117: 422-448.

Baker, Michael, and Dwayne Benjamin. 1994. The Performance of Immigrants in the Canadian Labor Market. Journal of Labor Economics 12(3): 369-405.

Bell, Ben D. 1997. The Performance of Immigrants in the United Kingdom: Evidence from the GHS. Economic Journal 107: 333-345.

Borjas, Georges. 1985. Assimilation, Changes in Cohort Quality, and the Earnings of Immigrants. Journal of Labor Economics 3(4): $463-489$.

----- 1995. Assimilation and Changes in Cohort Quality Revisited: What Happened to Immigrant Earnings in the 1980s?. Journal of Labor Economics 13(21): 201-245.

-----. 1999. The Economic Analysis of Immigration. In: Ashenfelter O, Card D (Eds), Handbook of Labor Economics, vol. 3, Elsevier Science: Amsterdam.

Bratsberg, Bernt, Erling Barth, and Oddbjørn Raaum. 2006. Local Unemployment and the relative wage of immigrants: evidence from the Current Population Surveys. Review of Economics and Statistics 88(2): 243-246.

Bratsberg, Bernt, and James Ragan. 2002. The Impact of Host-Country Schooling on Earnings. A Study of Male Immigrants in the United States. Journal of Human Resources XXXVII(1): 63-105.

Card, David. 1999. Causal Effect of Education on Earnings. In: Ashenfelter O, Card D (dir.), Handbook of Labor Economics, vol. 3, Elsevier Science: Amsterdam; 1801-1863.

Carrasco, Raquel, Juan Francisco Jimeno, and Carolina Ortega. 2008. The effect of immigration on the labor market performance of native-born workers: some evidence for Spain. Journal of Population Economics 21: 627-648.

Chiswick, Barry R.. 1978. The Effect of Americanization on the Earnings of Foreign-born Men. Journal of Political Economy 86(5): 897-921.

Chiswick, Barry R., Yew Liang Lee, and Paul W. Miller. 2005. Immigrant earnings: A Longitudinal Analysis. Review of Income and Wealth 51(4): 485-503.

Chiswick, Barry R., and Paul Miller. 1985. Immigrant Generation and Income in Australia. Economic Record 61(173): 540-553.

-----. 1995. The endogeneity between language and earnings: an international analysis. Journal of Labor Economics 13(2): 246-288.

-----. 2009. The International Transferability of Immigrants' Human Capital Skills. Economics of Education Review 28 (2): $162-169$.

-----. 2011. The "Negative" Assimilation of Immigrants: A Special Case. Industrial and Labor Relations Review 64 (3): $502-525$.

Clark, Ken, and Joanne Lindley. 2009. Immigrant assimilation pre and post labour market entry: evidence from the UK Labour Force Survey. Journal of Population Economics XXII(1): 175-198.

Constant, Amelie, and Douglas S Massey. 2003. Self-selection, earnings, and out-migration: A longitudinal study of immigrants to Germany. Journal of Population Economics 16: 631-653.

De la Rica, Sara, Albrecth Glitz, and Francesc Ortega. 2014. Immigration in Spain: What have we learned from recent evidence? Cuadernos económicos de ICE, $\mathrm{N}^{\circ}$ 87: 9-29.

Dustmann, Christian, and Yoram Weiss. 2007. Return Migration: Theory and Empirical Evidence from UK. British Journal of Industrial Relations 45(2): 236-256.

Fernández, Cristina, and Carolina Ortega. 2008. Labor market assimilation of immigrants in Spain: employment at the expense of bad jobmatches?. Spanish Economic Review 10(2); 83-107.

Fernández-Huertas Moraga, Jesús. 2014. Immigrant Selection over the Business Cycle: the Spanish Boom and the Great Recession. Cuadernos Económicos ICE 87: 57-84.Ferrer, Ana, David Green, and Craig Riddell. 2006. The Effect of Literacy on Immigrant Earnings. Journal of Human Resources XLI(2): 380-410.

Ferrer, Ana, and Craig Riddell. 2003. Education, credentials, and immigrant earnings. Canadian Journal of Economics 41(1): 186-216. 
Friedberg, Rachel. 2000. You Can't Take It with You? Immigrant Assimilation and the Portability of Human Capital. Journal of Labor Economics 18(2); 221-251.

Galloway, Taryn Ann. 2008. Re-examining the Earnings Assimilation of Immigrants. Statistics Norway Research Department Discussion Paper 570.

González, Libertad, and Francesc Ortega. 2011. How do very open economies adjust to large immigration flows? Evidence from Spanish regions. Labour Economics 18(1): 57-70.

Hartog, Joop, and Asland Zorlu. 2009. How important is homeland education for refugees' economic position in The Netherlands?. Journal of Population Economics 22: 219-246.

Izquierdo, Mario, Aitor Lacuesta, and Raquel Vegas. 2009. Assimilation of Immigrants in Spain: A Longitudinal Analysis. Labour Economics 16(6): 669-678.

Kossoudji, Sherrie. 1989. Immigrant Worker Assimilation: Is It a Labor Market Phenomenon?. Journal of Human Resources XXIV (3): $494-527$.

Lubotsky, Darren. 2007. Chutes or Ladders? A Longitudinal Analysis of Immigrant Earnings. Journal of Political Economy 115(5): 820-867.

OECD. 2011. International Migration Outlook, Annual Report 2011. OECD: Paris.

Psacharopoulos, George, and Harry Anthony Patrinos. 2004. Returns to investment in education: A further update. Education Economics 12(2): $111-134$.

Reher, David et al. 2008. Informe Encuesta Nacional de Inmigrantes (ENI-07), Documentos de Trabajo INE 2-08.

Sanromá, Esteban, Raúl Ramos, and Hipólito Simón. 2008. The Portability of Human Capital and Immigrant Assimilation: Evidence for Spain. IZA Discussion Paper 3649.

Schaafsma, Joseph, and Arthur Sweetman. 2001. Immigrant earnings: age at immigration matters. Canadian Journal of Economics 34(4): 10661099.

Simón, Hipólito, Esteban Sanromá, and Raúl Ramos. 2008. Labour Segregation and Immigrant and Native-born Wage Distributions in Spain: An Analysis Using Matched Employer-Employee Data. Spanish Economic Review 10(2): 135-168.

Skuterud, Mikal, and Mingcui Su. 2012. The influence of measurement error and unobserved heterogeneity in estimating immigrant returns to foreign and host-country sources of human capital. Empirical Economics 43 (3): 1109-1141. 


\section{TABLES}

Table 1. Returns to domestic and foreign human capital

\begin{tabular}{|c|c|c|c|}
\hline Logarithm of hourly wages & Model (1) & Model (2) & Model (3) \\
\hline \multirow{2}{*}{ Years since migration } & $0.0166^{\star * *}$ & & \\
\hline & {$[0.00273]$} & & \\
\hline \multirow[t]{2}{*}{ Schooling years } & $0.0148^{\star \star \star}$ & & \\
\hline & [0.00183] & & \\
\hline \multirow[t]{2}{*}{ Schooling years in Spain } & & $0.0376^{\star \star \star}$ & $0.0424^{\star \star \star}$ \\
\hline & & [0.00852] & {$[0.00850]$} \\
\hline \multirow[t]{2}{*}{ Schooling years in home country } & & $0.0147^{* * *}$ & $0.0143^{* * *}$ \\
\hline & & {$[0.00183]$} & {$[0.00184]$} \\
\hline \multirow[t]{2}{*}{ Potential experience in Spain } & & 0.0144 & \\
\hline & & {$[0.00901]$} & \\
\hline \multirow[t]{2}{*}{ Potential experience in Spain² } & & 0.00022 & \\
\hline & & {$[0.000981]$} & \\
\hline \multirow[t]{2}{*}{ Effective experience in Spain } & & & $0.0233^{* * *}$ \\
\hline & & & {$[0.00793]$} \\
\hline \multirow[t]{2}{*}{ Effective experience in Spain ${ }^{2}$} & & & -0.000575 \\
\hline & & & {$[0.000949]$} \\
\hline \multirow[t]{2}{*}{ Unemployment years in Spain } & & & 0.000944 \\
\hline & & & {$[0.00497]$} \\
\hline \multirow[t]{2}{*}{ Potential experience in home country } & $0.00698^{* * *}$ & $0.00704^{* * *}$ & $0.00644^{* * *}$ \\
\hline & {$[0.00195]$} & {$[0.00195]$} & {$[0.00195]$} \\
\hline \multirow[t]{2}{*}{ Potential experience in home country ${ }^{2}$} & $-0.000242^{\star \star \star}$ & $-0.000243^{\star \star \star}$ & $-0.000240^{\star * *}$ \\
\hline & {$[5.68 \mathrm{e}-05]$} & {$[5.69 \mathrm{e}-05]$} & {$[5.68 \mathrm{e}-05]$} \\
\hline \multirow[t]{2}{*}{ Labour experience in home country } & & & $0.0399^{* * *}$ \\
\hline & & & {$[0.0154]$} \\
\hline \multirow[t]{2}{*}{ Heckman's lambda } & $0.0552^{* *}$ & $0.0534^{\star *}$ & $0.0783^{\star * *}$ \\
\hline & {$[0.0247]$} & [0.0249] & {$[0.0246]$} \\
\hline Number of observations & 4143 & 4143 & 4143 \\
\hline Adjusted $\mathrm{R}^{2}$ & 0.214 & 0.214 & 0.218 \\
\hline
\end{tabular}

Notes: OLS estimates with controls related to gender, civil status, geographical area of birth, legal status, having more than one job and the region of residence. ${ }^{* * *},{ }^{* *}$ and ${ }^{*}$ indicate that the estimated coefficient is statistically different from zero at $1 \%, 5 \%$, and $10 \%$ significance levels, respectively. 
Table 2. Returns to domestic and foreign human capital by region of origin

\begin{tabular}{|c|c|c|c|c|c|}
\hline Logarithm of hourly wages & Developed countries & Developing countries & Latin America & Eastern Europe & Rest of the world \\
\hline \multirow[t]{2}{*}{ Schooling years in Spain } & $0.0400^{\star}$ & $0.0402^{* \star *}$ & $0.0454^{\star \star \star}$ & $0.0392^{*}$ & $0.0441^{* \star}$ \\
\hline & {$[0.0237]$} & {$[0.00908]$} & {$[0.0120]$} & {$[0.0210]$} & {$[0.0184]$} \\
\hline \multirow[t]{2}{*}{ Schooling years in home country } & $0.0564^{* * *}$ & $0.0119^{\star * *}$ & $0.0129^{\star \star \star}$ & $0.00893^{\star *}$ & $0.00560^{\star}$ \\
\hline & {$[0.00831]$} & {$[0.00188]$} & {$[0.00261]$} & {$[0.00422]$} & {$[0.00328]$} \\
\hline \multirow[t]{2}{*}{ Effective experience in Spain } & 0.0188 & $0.0221^{\star * *}$ & $0.0266^{\star *}$ & 0.0189 & 0.00155 \\
\hline & [0.0298] & {$[0.00826]$} & [0.0113] & {$[0.0174]$} & {$[0.0180]$} \\
\hline \multirow[t]{2}{*}{ Effective experience in Spain ${ }^{2}$} & -0.000808 & -0.000872 & -0.00087 & -0.000904 & 0.00193 \\
\hline & {$[0.00331]$} & {$[0.000978]$} & {$[0.00136]$} & {$[0.00211]$} & {$[0.00196]$} \\
\hline \multirow[t]{2}{*}{ Unemployment years in Spain } & $-0.0940^{* * *}$ & -0.00265 & 0.0086 & -0.0189 & 0.00764 \\
\hline & {$[0.0252]$} & [0.00493] & {$[0.00670]$} & {$[0.0115]$} & {$[0.0101]$} \\
\hline \multirow[t]{2}{*}{ Potential exp. in home country } & 0.0123 & $0.00322^{*}$ & $0.00936^{\star \star *}$ & 0.00179 & -0.00268 \\
\hline & {$[0.0111]$} & [0.00195] & [0.00259] & {$[0.00392]$} & {$[0.00560]$} \\
\hline \multirow[t]{2}{*}{ Potential exp. in home country ${ }^{2}$} & -0.000104 & $-0.000156^{\star * *}$ & $-0.000320^{* \star *}$ & -0.000153 & $-1.47 \mathrm{E}-05$ \\
\hline & {$[0.000312]$} & [5.62e-05] & [7.45e-05] & {$[0.000114]$} & [0.000165] \\
\hline \multirow{2}{*}{ Labor experience in home country } & -0.0308 & $0.0389^{\star \star}$ & $0.0624^{\star \star \star}$ & 0.0123 & 0.0389 \\
\hline & [0.0749] & {$[0.0167]$} & [0.0232] & {$[0.0329]$} & [0.0298] \\
\hline \multirow[t]{2}{*}{ Heckman's lambda } & -0.0739 & -0.00328 & $0.111^{\star * *}$ & -0.0117 & 0.0202 \\
\hline & {$[0.142]$} & {$[0.0347]$} & {$[0.0312]$} & [0.102] & [0.0423] \\
\hline Number of observations & 278 & 3,865 & 2,225 & 1,121 & 519 \\
\hline Adjusted $\mathrm{R}^{2}$ & 0.329 & 0.181 & 0.183 & 0.245 & 0.205 \\
\hline
\end{tabular}

Notes: OLS estimates with controls related to gender, civil status, geographical area of birth, legal status, having more than one job and the region of. *** ${ }^{* *}$ and * indicate that the estimated coefficient is statistically different from zero at $1 \%, 5 \%$, and $10 \%$ significance levels, respectively. 


\section{APPENDIX}

Table A.1. Descriptive statistics

\begin{tabular}{|c|c|c|c|c|c|c|}
\hline \multirow[b]{2}{*}{ Descriptive statistics } & \multirow[b]{2}{*}{ Full sample } & \multirow[b]{2}{*}{ Developed countries } & \multicolumn{4}{|c|}{ Developing countries } \\
\hline & & & Total & Latin America & Eastern Europe & Rest of the world \\
\hline \multirow[t]{2}{*}{ Hourly wage } & 1.671 & 1.936 & 1.651 & 1.651 & 1.656 & 1.643 \\
\hline & {$[0.00556]$} & {$[0.0253]$} & {$[0.00556]$} & {$[0.00754]$} & {$[0.0105]$} & {$[0.0125]$} \\
\hline Male & {$[0.00775]$} & {$[0.0298]$} & [0.00803] & {$[0.0106]$} & {$[0.0149]$} & {$[0.0171]$} \\
\hline \multirow[t]{2}{*}{ Married } & 0.491 & 0.345 & 0.502 & 0.466 & 0.554 & 0.543 \\
\hline & {$[0.00777]$} & {$[0.0286]$} & {$[0.00804]$} & {$[0.0106]$} & [0.0149] & [0.0219] \\
\hline \multirow[t]{2}{*}{ Children } & 0.681 & 0.486 & 0.695 & 0.751 & 0.637 & 0.584 \\
\hline & {$[0.0146]$} & [0.0485] & [0.0152] & [0.0210] & [0.0242] & {$[0.0451]$} \\
\hline \multirow[t]{2}{*}{ Age of arrival to Spain } & 29.56 & 30.54 & 29.49 & 29.83 & 29.75 & 27.45 \\
\hline & {$[0.130]$} & [0.508] & {$[0.135]$} & {$[0.180]$} & [0.259] & [0.302] \\
\hline \multirow[t]{2}{*}{ Years since migration } & 4.336 & 4.119 & 4.351 & 4.397 & 3.897 & 5.135 \\
\hline & {$[0.0327]$} & {$[0.155]$} & [0.0332] & [0.0435] & {$[0.0567]$} & [0.0969] \\
\hline Schooling years in Spain & {$[0.00961]$} & {$[0.0464]$} & {$[0.00974]$} & {$[0.0137]$} & [0.0142] & {$[0.0294]$} \\
\hline \multirow[t]{2}{*}{ Potential experience } & 16.81 & 16.64 & 16.82 & 17.07 & 16.24 & 17.02 \\
\hline & [0.139] & {$[0.563]$} & {$[0.143]$} & {$[0.192]$} & {$[0.269]$} & {$[0.343]$} \\
\hline \multirow[t]{2}{*}{ Potential exp. in home country } & 12.61 & 12.71 & 12.6 & 12.82 & 12.43 & 12.03 \\
\hline & {$[0.136]$} & {$[0.557]$} & {$[0.140]$} & {$[0.188]$} & {$[0.263]$} & {$[0.334]$} \\
\hline \multirow[t]{2}{*}{ Potential exp. in Spain } & 4.197 & 3.924 & 4.216 & 4.244 & 3.806 & 4.983 \\
\hline & {$[0.0330]$} & {$[0.157]$} & {$[0.0335]$} & {$[0.0441]$} & [0.0573] & {$[0.0966]$} \\
\hline \multirow[t]{2}{*}{ Effective experience } & 3.554 & 3.550 & 3.554 & 3.632 & 3.202 & 3.979 \\
\hline & {$[0.0340]$} & {$[0.153]$} & {$[0.0347]$} & {$[0.0455]$} & {$[0.0602]$} & {$[0.105]$} \\
\hline \multirow[t]{2}{*}{ Non-employment years } & 0.643 & 0.375 & 0.662 & 0.612 & 0.605 & 1.004 \\
\hline & {$[0.0172]$} & {$[0.0504]$} & {$[0.0180]$} & {$[0.0230]$} & [0.0293] & {$[0.0640]$} \\
\hline Legal status & 0.87 & 0.996 & 0.861 & 0.888 & 0.775 & 0.933 \\
\hline
\end{tabular}

Notes: Values correspond to the variable averages. Standard deviation is shown in brackets. 
Table A.1. Descriptive statistics (continuation)

\begin{tabular}{|c|c|c|c|c|c|c|}
\hline \multirow{2}{*}{ Descriptive statistics } & \multirow{2}{*}{ Full sample } & \multirow{2}{*}{ Developed countries } & \multicolumn{4}{|c|}{ Developing countries } \\
\hline & & & Total & Latin America & Eastern Europe & Rest of the world \\
\hline \multirow[t]{2}{*}{ Having more than one job } & 0.0625 & 0.0647 & 0.0624 & 0.071 & 0.0633 & 0.0231 \\
\hline & {$[0.00376]$} & {$[0.0148]$} & {$[0.00389]$} & {$[0.00545]$} & {$[0.00728]$} & {$[0.00660]$} \\
\hline \multirow[t]{2}{*}{ Developed country } & 0.0671 & 1 & 0 & 0 & 0 & 0 \\
\hline & {$[0.00389]$} & {$[0]$} & [0] & [0] & [0] & {$[0]$} \\
\hline \multirow[t]{2}{*}{ Developing country } & 0.537 & 0 & 0.576 & 1 & 0 & 0 \\
\hline & {$[0.00775]$} & {$[0]$} & {$[0.00795]$} & [0] & {$[0]$} & {$[0]$} \\
\hline \multirow[t]{2}{*}{ Latin America } & 0.271 & 0 & 0.29 & 0 & 1 & 0 \\
\hline & {$[0.00690]$} & {$[0]$} & {$[0.00730]$} & [0] & [0] & [0] \\
\hline \multirow[t]{2}{*}{ Eastern Europe } & 0.125 & 0 & 0.134 & 0 & 0 & 1 \\
\hline & {$[0.00514]$} & {$[0]$} & [0.00549] & {$[0]$} & {$[0]$} & [0] \\
\hline \multirow[t]{2}{*}{ Rest of the world } & 0.0606 & 0.0971 & 0.058 & 0.0485 & 0.0687 & 0.0751 \\
\hline & {$[0.00371]$} & {$[0.0178]$} & {$[0.00376]$} & {$[0.00456]$} & {$[0.00756]$} & {$[0.0116]$} \\
\hline \multirow[t]{2}{*}{ Andalucía } & 0.0449 & 0.018 & 0.0468 & 0.027 & 0.0767 & 0.0674 \\
\hline & {$[0.00322]$} & {$[0.00799]$} & {$[0.00340]$} & {$[0.00343]$} & {$[0.00795]$} & {$[0.0110]$} \\
\hline \multirow[t]{2}{*}{ Aragón } & 0.0113 & 0.018 & 0.0109 & 0.0135 & 0.00892 & 0.00385 \\
\hline & {$[0.00165]$} & [0.00799] & {$[0.00167]$} & {$[0.00245]$} & [0.00281] & [0.00272] \\
\hline \multirow[t]{2}{*}{ Asturias } & 0.063 & 0.108 & 0.0598 & 0.0728 & 0.0348 & 0.0578 \\
\hline & {$[0.00378]$} & {$[0.0186]$} & {$[0.00381]$} & {$[0.00551]$} & {$[0.00548]$} & {$[0.0103]$} \\
\hline \multirow[t]{2}{*}{ Baleares } & 0.0314 & 0.0791 & 0.0279 & 0.0378 & 0.00981 & 0.025 \\
\hline & {$[0.00271]$} & {$[0.0162]$} & {$[0.00265]$} & {$[0.00404]$} & [0.00295] & {$[0.00687]$} \\
\hline \multirow[t]{2}{*}{ Canarias } & 0.0258 & 0.0108 & 0.0269 & 0.0337 & 0.0241 & 0.00385 \\
\hline & {$[0.00246]$} & {$[0.00621]$} & {$[0.00260]$} & [0.00383] & {$[0.00458]$} & [0.00272] \\
\hline \multirow[t]{2}{*}{ Cantabria } & 0.0374 & 0.0252 & 0.0383 & 0.0274 & 0.0624 & 0.0328 \\
\hline & {$[0.00295]$} & {$[0.00941]$} & {$[0.00309]$} & {$[0.00346]$} & {$[0.00723]$} & {$[0.00782]$} \\
\hline \multirow[t]{2}{*}{ Castilla y León } & 0.0574 & 0.00719 & 0.0611 & 0.0355 & 0.129 & 0.0231 \\
\hline & {$[0.00362]$} & {$[0.00508]$} & {$[0.00385]$} & [0.00392] & {$[0.0100]$} & {$[0.00660]$} \\
\hline \multirow[t]{2}{*}{ Castilla-La Mancha } & 0.135 & 0.173 & 0.132 & 0.143 & 0.0856 & 0.185 \\
\hline & {$[0.00531]$} & {$[0.0227]$} & {$[0.00545]$} & {$[0.00743]$} & {$[0.00836]$} & {$[0.0171]$} \\
\hline \multirow[t]{2}{*}{ Cataluña } & 0.0867 & 0.112 & 0.0849 & 0.0661 & 0.117 & 0.0963 \\
\hline & {$[0.00437]$} & {$[0.0189]$} & {$[0.00448]$} & {$[0.00527]$} & {$[0.00960]$} & {$[0.0130]$} \\
\hline \multirow[t]{2}{*}{ Comunidad Valenciana } & 0.0203 & 0.0288 & 0.0197 & 0.0189 & 0.0205 & 0.0212 \\
\hline & {$[0.00219]$} & {$[0.0100]$} & {$[0.00223]$} & {$[0.00289]$} & {$[0.00424]$} & {$[0.00633]$} \\
\hline \multirow[t]{2}{*}{ Extremadura } & 0.0171 & 0.00719 & 0.0179 & 0.0252 & 0.00624 & 0.0116 \\
\hline & [0.00202] & {$[0.00508]$} & {$[0.00213]$} & {$[0.00332]$} & {$[0.00235]$} & {$[0.00470]$} \\
\hline
\end{tabular}

Notes: Values correspond to the variable averages. Standard deviation is shown in brackets. 
Table A.1. Descriptive statistics (continuation)

\begin{tabular}{|c|c|c|c|c|c|c|}
\hline \multirow{2}{*}{ Descriptive statistics } & \multirow{2}{*}{ Full sample } & \multirow{2}{*}{ Developed countries } & \multicolumn{4}{|c|}{ Developing countries } \\
\hline & & & Total & Latin America & Eastern Europe & Rest of the world \\
\hline \multirow[t]{2}{*}{ Galicia } & 0.149 & 0.119 & 0.152 & 0.174 & 0.14 & 0.079 \\
\hline & {$[0.00554]$} & {$[0.0194]$} & {$[0.00577]$} & {$[0.00805]$} & {$[0.0104]$} & {$[0.0119]$} \\
\hline \multirow[t]{2}{*}{ Madrid } & 0.0992 & 0.0576 & 0.102 & 0.108 & 0.0633 & 0.16 \\
\hline & {$[0.00464]$} & {$[0.0140]$} & {$[0.00487]$} & [0.00659] & {$[0.00728]$} & {$[0.0161]$} \\
\hline \multirow[t]{2}{*}{ Murcia } & 0.0922 & 0.0935 & 0.0921 & 0.107 & 0.0696 & 0.079 \\
\hline & {$[0.00450]$} & {$[0.0175]$} & {$[0.00465]$} & {$[0.00654]$} & {$[0.00760]$} & {$[0.0119]$} \\
\hline \multirow[t]{2}{*}{ Navarra } & 0.0253 & 0.0324 & 0.0248 & 0.0306 & 0.0125 & 0.027 \\
\hline & {$[0.00244]$} & {$[0.0106]$} & {$[0.00250]$} & {$[0.00365]$} & [0.00332] & [0.00712] \\
\hline \multirow[t]{2}{*}{ País Vasco } & 0.0415 & 0.0144 & 0.0435 & 0.0301 & 0.0705 & 0.0424 \\
\hline & {$[0.00310]$} & {$[0.00716]$} & [0.00328] & {$[0.00362]$} & {$[0.00765]$} & [0.00885] \\
\hline \multirow[t]{2}{*}{ Rioja } & 0.042 & 0.014 & 0.044 & 0.03 & 0.071 & 0.042 \\
\hline & {$[0.00310]$} & {$[0.00716]$} & [0.00328] & {$[0.00362]$} & {$[0.00765]$} & [0.00885] \\
\hline Number of observations & 4,143 & 278 & 3,865 & 2,225 & 1,121 & 519 \\
\hline
\end{tabular}

Notes: Values correspond to the variable averages. Standard deviation is shown in brackets. 
Table A.2. Probit marginal effects for employment

\begin{tabular}{|c|c|c|c|c|c|c|}
\hline & Full sample & Developed countries & Developing countries & Latin America & Eastern Europe & Rest of the world \\
\hline \multirow[t]{2}{*}{ Years since migration } & $0.0184^{* * *}$ & $0.0335^{* * *}$ & $0.0160^{* * *}$ & $0.0119^{* \star *}$ & 0.00615 & $0.0366^{\star \star \star}$ \\
\hline & [0.00264] & {$[0.00751]$} & [0.00287] & [0.00373] & [0.00607] & {$[0.00741]$} \\
\hline \multirow[t]{2}{*}{ Schooling years } & 0.00254 & $-0.0121^{* *}$ & $0.00493^{\star * \star}$ & 0.00123 & $0.0101^{\star * \star}$ & $0.00784^{*}$ \\
\hline & {$[0.00169]$} & [0.00605] & {$[0.00177]$} & [0.00243] & [0.00352] & {$[0.00442]$} \\
\hline \multirow[t]{2}{*}{ Potential experience } & $0.0236^{* \star *}$ & $0.0246^{* \star *}$ & $0.0179^{\star \star \star}$ & $0.0194^{\star * \star}$ & $0.0115^{\star \star \star}$ & $0.0260^{* \star \star}$ \\
\hline & {$[0.00193]$} & {$[0.00658]$} & {$[0.00211]$} & {$[0.00262]$} & {$[0.00404]$} & {$[0.00675]$} \\
\hline \multirow[t]{2}{*}{ Potential experience ${ }^{2}$} & $-0.000550^{\star * \star}$ & $-0.000845^{\star \star *}$ & $-0.000338^{* * *}$ & $-0.000368^{* * *}$ & $-0.000227^{* *}$ & $-0.000452^{\star \star \star}$ \\
\hline & {$[4.12 \mathrm{e}-05]$} & {$[0.000132]$} & {$[4.76 \mathrm{e}-05]$} & {$[5.80 \mathrm{e}-05]$} & {$[9.33 e-05]$} & {$[0.000157]$} \\
\hline \multirow[t]{2}{*}{ Labor experience in home country } & $0.116^{\star \star \star}$ & $0.162^{* * *}$ & $0.111^{\star \star \star}$ & $0.107^{* \star *}$ & $0.0753^{* *}$ & $0.137^{\star \star \star}$ \\
\hline & [0.0155] & [0.0587] & {$[0.0158]$} & {$[0.0222]$} & [0.0302] & {$[0.0370]$} \\
\hline \multirow[t]{2}{*}{ Legal status } & $0.116^{* * *}$ & 0.220 & $0.114^{\star * \star}$ & $0.0813^{\star \star \star}$ & $0.140^{* * *}$ & $0.234^{\star * \star}$ \\
\hline & [0.0164] & {$[0.191]$} & [0.0163] & [0.0222] & [0.0258] & [0.0524] \\
\hline \multirow[t]{2}{*}{ Male } & $0.168^{\star * \star}$ & $0.212^{\star \star \star}$ & $0.167^{\star \star \star}$ & $0.137^{\star * *}$ & $0.135^{\star \star \star}$ & $0.322^{\star \star \star}$ \\
\hline & [0.0101] & {$[0.0351]$} & [0.0104] & {$[0.0131]$} & [0.0188] & [0.0320] \\
\hline \multirow[t]{2}{*}{ Married } & $-0.0500^{\star * *}$ & $-0.0885^{\star *}$ & $-0.0330^{* \star *}$ & -0.0196 & -0.0116 & $-0.116^{* \star *}$ \\
\hline & [0.0112] & {$[0.0394]$} & {$[0.0116]$} & {$[0.0147]$} & {$[0.0214]$} & {$[0.0369]$} \\
\hline \multirow[t]{2}{*}{ Children } & $-0.0366^{* * *}$ & -0.0355 & $-0.0412^{* \star *}$ & $-0.0315^{\star * *}$ & $-0.0520^{* * *}$ & $-0.0499^{* * *}$ \\
\hline & {$[0.00576]$} & {$[0.0234]$} & {$[0.00584]$} & {$[0.00734]$} & {$[0.0126]$} & {$[0.0157]$} \\
\hline Number of observations & 8,482 & 1,022 & 7,460 & 4,177 & 2,062 & 1,221 \\
\hline Pseudo- $R^{2}$ & 0.1190 & 0.2477 & 0.1089 & 0.0795 & 0.0875 & 0.2265 \\
\hline
\end{tabular}

Notes: All estimates include controls for the region of residence. ${ }^{* * *},{ }^{* *}$ and ${ }^{*}$ indicate that the estimated coefficient is statistically different from zero at $1 \%, 5 \%$, and $10 \%$ significance levels, respectively. 
Table A.3. Detailed results of the estimation in Tables 1 and 2

\begin{tabular}{|c|c|c|c|c|c|c|}
\hline Logarithm of hourly wages & Full sample & Developed countries & Developing countries & Latin America & Eastern Europe & Rest of the world \\
\hline \multirow[t]{2}{*}{ Schooling years in Spain } & $0.0424^{\star * *}$ & $0.0400^{*}$ & $0.0402^{* * *}$ & $0.0454^{* * *}$ & $0.0392^{*}$ & $0.0441^{* *}$ \\
\hline & {$[0.00850]$} & {$[0.0237]$} & {$[0.00908]$} & {$[0.0120]$} & {$[0.0210]$} & {$[0.0184]$} \\
\hline \multirow[t]{2}{*}{ Schooling years in home country } & $0.0143^{* * *}$ & $0.0564^{* * *}$ & $0.0119^{* * *}$ & $0.0129 * * *$ & $0.00893^{* *}$ & $0.00560^{*}$ \\
\hline & {$[0.00184]$} & [0.00831] & [0.00188] & [0.00261] & [0.00422] & {$[0.00328]$} \\
\hline \multirow[t]{2}{*}{ Effective experience in Spain } & $0.0233^{* * *}$ & 0.0188 & $0.0221^{* * *}$ & $0.0266^{\star *}$ & 0.0189 & 0.00155 \\
\hline & {$[0.00793]$} & {$[0.0298]$} & {$[0.00826]$} & {$[0.0113]$} & {$[0.0174]$} & {$[0.0180]$} \\
\hline \multirow[t]{2}{*}{ Effective experience in Spain ${ }^{2}$} & -0.000575 & -0.000808 & -0.000872 & -0.00087 & -0.000904 & 0.00193 \\
\hline & [0.000949] & {$[0.00331]$} & {$[0.000978]$} & {$[0.00136]$} & {$[0.00211]$} & {$[0.00196]$} \\
\hline \multirow[t]{2}{*}{ Unemployment years in Spain } & 0.000944 & $-0.0940^{* * *}$ & -0.00265 & 0.0086 & -0.0189 & 0.00764 \\
\hline & {$[0.00497]$} & [0.0252] & [0.00493] & {$[0.00670]$} & {$[0.0115]$} & {$[0.0101]$} \\
\hline \multirow[t]{2}{*}{ Potential exp. in home country } & $0.00644^{* * *}$ & 0.0123 & $0.00322^{*}$ & $0.00936^{* * *}$ & 0.00179 & -0.00268 \\
\hline & [0.00195] & {$[0.0111]$} & [0.00195] & [0.00259] & {$[0.00392]$} & {$[0.00560]$} \\
\hline \multirow[t]{2}{*}{ Potential exp. in home country ${ }^{2}$} & $-0.000240^{\star * \star}$ & -0.000104 & $-0.000156^{\star \star \star}$ & $-0.000320^{* \star \star}$ & -0.000153 & $-1.47 \mathrm{E}-05$ \\
\hline & {$[5.68 e-05]$} & [0.000312] & {$[5.62 e-05]$} & {$[7.45 e-05]$} & [0.000114] & {$[0.000165]$} \\
\hline \multirow[t]{2}{*}{ Labor exp. in home country } & $0.0399 * * *$ & -0.0308 & $0.0389^{* *}$ & $0.0624^{\star * \star}$ & 0.0123 & 0.0389 \\
\hline & [0.0154] & [0.0749] & [0.0167] & [0.0232] & [0.0329] & [0.0298] \\
\hline \multirow[t]{2}{*}{ Legal status } & $0.132^{\star \star \star}$ & 0.0866 & $0.110^{\star \star \star}$ & $0.145^{\star \star \star}$ & $0.126^{\star * \star}$ & $0.134^{\star *}$ \\
\hline & {$[0.0174]$} & [0.112] & {$[0.0177]$} & {$[0.0266]$} & {$[0.0271]$} & {$[0.0529]$} \\
\hline \multirow[t]{2}{*}{ Having more than one job } & 0.0249 & -0.0163 & 0.0266 & 0.0276 & 0.0156 & 0.0713 \\
\hline & {$[0.0236]$} & {$[0.102]$} & {$[0.0241]$} & {$[0.0310]$} & {$[0.0449]$} & {$[0.0723]$} \\
\hline \multirow[t]{2}{*}{ Heckman's lambda } & $0.0783^{* * *}$ & -0.0739 & -0.00328 & $0.111^{* \star *}$ & -0.0117 & 0.0202 \\
\hline & {$[0.0246]$} & {$[0.142]$} & {$[0.0347]$} & {$[0.0312]$} & [0.102] & {$[0.0423]$} \\
\hline \multirow[t]{2}{*}{ Male } & $0.234^{\star \star \star}$ & $0.131^{*}$ & $0.207^{\star \star \star}$ & $0.229^{* * \star}$ & $0.252^{* * *}$ & $0.173^{\star * \star}$ \\
\hline & {$[0.0120]$} & {$[0.0728]$} & {$[0.0123]$} & {$[0.0151]$} & [0.0262] & {$[0.0374]$} \\
\hline \multirow[t]{2}{*}{ Married } & $0.0332^{\star * *}$ & 0.0384 & $0.0405^{\star \star \star}$ & $0.0348^{* *}$ & 0.0189 & $0.0561^{*}$ \\
\hline & {$[0.0107]$} & {$[0.0549]$} & {$[0.0110]$} & {$[0.0147]$} & {$[0.0209]$} & [0.0292] \\
\hline Number of observations & 4,143 & 278 & 3,865 & 2,225 & 1,121 & 519 \\
\hline Adjusted $\mathrm{R}^{2}$ & 0.218 & 0.329 & 0.181 & 0.183 & 0.245 & 0.205 \\
\hline
\end{tabular}

Notes: All estimates include controls for the region of residence. ${ }^{* \star *},{ }^{* *}$ and ${ }^{*}$ indicate that the estimated coefficient is statistically different from zero at $1 \%, 5 \%$, and $10 \%$ significance levels, respectively. 
Table A.4. Robustness check to the use of schooling levels instead of schooling years

\begin{tabular}{|c|c|c|c|c|c|c|}
\hline Logarithm of hourly wages & Full sample & Developed countries & Developing countries & Latin America & Eastern Europe & Rest of the world \\
\hline \multirow[t]{2}{*}{ Age } & $0.0211^{\star \star \star}$ & 0.0192 & $0.0143^{\star \star \star}$ & $0.0193^{\star * \star}$ & $0.0221^{\star \star}$ & $0.0238^{*}$ \\
\hline & {$[0.00533]$} & {$[0.0386]$} & {$[0.00473]$} & {$[0.00655]$} & {$[0.00963]$} & {$[0.0126]$} \\
\hline \multirow[t]{2}{*}{ Age squared } & $-0.000299 * * *$ & -0.000151 & $-0.000213^{\star \star \star}$ & $-0.000273^{\star \star \star}$ & $-0.000329^{\star *}$ & $-0.000379^{* *}$ \\
\hline & [7.31e-05] & {$[0.000528]$} & [6.40e-05] & [8.84e-05] & {$[0.000129]$} & {$[0.000177]$} \\
\hline \multirow[t]{2}{*}{ Primary studies } & -0.0197 & -0.0825 & $-0.0260^{\star *}$ & -0.00813 & -0.00743 & -0.0211 \\
\hline & [0.0129] & {$[0.0655]$} & {$[0.0131]$} & {$[0.0177]$} & [0.0299] & {$[0.0262]$} \\
\hline \multirow[t]{2}{*}{ Tertiary studies } & $0.130^{* * *}$ & $0.333^{\star * *}$ & $0.105^{* * *}$ & $0.114^{* * *}$ & $0.0929^{* * *}$ & $0.114^{* *}$ \\
\hline & {$[0.0159]$} & {$[0.0577]$} & [0.0165] & {$[0.0212]$} & {$[0.0319]$} & {$[0.0441]$} \\
\hline \multirow[t]{2}{*}{ Primary studies in Spain } & 0.0126 & -0.106 & 0.0424 & 0.0518 & $0.375^{\star \star \star}$ & 0.015 \\
\hline & {$[0.0708]$} & {$[0.101]$} & {$[0.0766]$} & {$[0.106]$} & {$[0.109]$} & {$[0.113]$} \\
\hline \multirow[t]{2}{*}{ Secondary studies in Spain } & 0.0105 & -0.0488 & 0.0173 & -0.0213 & 0.057 & 0.116 \\
\hline & {$[0.0262]$} & [0.103] & {$[0.0269]$} & {$[0.0348]$} & [0.0469] & {$[0.0724]$} \\
\hline \multirow[t]{2}{*}{ Tertiary studies in Spain } & $0.103^{\star *}$ & 0.024 & $0.126^{* *}$ & $0.139^{* *}$ & 0.0394 & 0.179 \\
\hline & {$[0.0478]$} & {$[0.107]$} & {$[0.0531]$} & {$[0.0592]$} & {$[0.154]$} & [0.142] \\
\hline \multirow[t]{2}{*}{ Labour exp. in home country } & 0.0153 & -0.00556 & 0.0205 & 0.0319 & 0.00434 & 0.0128 \\
\hline & {$[0.0155]$} & {$[0.0685]$} & [0.0169] & {$[0.0238]$} & [0.0323] & {$[0.0294]$} \\
\hline \multirow[t]{2}{*}{ Heckman's lambda } & 0.028 & -0.0354 & -0.0424 & 0.019 & 0.0128 & 0.0101 \\
\hline & {$[0.0265]$} & {$[0.134]$} & {$[0.0383]$} & {$[0.0453]$} & {$[0.101]$} & {$[0.0372]$} \\
\hline Number of observations & 4,143 & 278 & 3,865 & 2,225 & 1,121 & 519 \\
\hline Adjusted $\mathrm{R}^{2}$ & 0.219 & 0.330 & 0.179 & 0.184 & 0.240 & 0.207 \\
\hline
\end{tabular}

Notes: OLS estimates with controls related to gender, civil status, legal status geographical area of birth andthe region of residence. ${ }^{* * *}$, ${ }^{* *}$ and ${ }^{*}$ indicate that the estimated coefficient is statistically different from zero at $1 \%, 5 \%$, and $10 \%$ significance levels, respectively. 


\section{Table A.5. Robustness checks to different sample selection}

\begin{tabular}{|c|c|c|c|}
\hline Logarithm of hourly wages & Legal status & Only one job & $\begin{array}{l}\text { Only one job, and without coming } \\
\text { from third countries }\end{array}$ \\
\hline \multirow[t]{2}{*}{ Schooling years in Spain } & $0.0411^{* * *}$ & $0.0407^{\star \star \star}$ & $0.0368^{* \star *}$ \\
\hline & {$[0.00869]$} & {$[0.00885]$} & {$[0.00905]$} \\
\hline \multirow[t]{2}{*}{ Schooling years in home country } & $0.0155^{\star \star \star}$ & $0.0138^{\star \star \star}$ & $0.0124^{\star \star \star}$ \\
\hline & [0.00196] & [0.00188] & {$[0.00193]$} \\
\hline \multirow[t]{2}{*}{ Effective experience in Spain } & $0.0191^{* *}$ & $0.0239^{\star \star \star *}$ & $0.0293^{\star * *}$ \\
\hline & {$[0.00879]$} & {$[0.00816]$} & {$[0.00836]$} \\
\hline \multirow[t]{2}{*}{ Effective experience in Spain ${ }^{2}$} & -0.000187 & -0.000576 & -0.00114 \\
\hline & {$[0.00102]$} & {$[0.000981]$} & [0.000989] \\
\hline \multirow[t]{2}{*}{ Unemployment years in Spain } & 0.000814 & 0.000352 & -0.000108 \\
\hline & {$[0.00524]$} & {$[0.00512]$} & {$[0.00527]$} \\
\hline \multirow[t]{2}{*}{ Potential exp. in home country } & $0.00448^{\star *}$ & $0.00683^{\star \star *}$ & $0.00621^{\star * *}$ \\
\hline & {$[0.00209]$} & {$[0.00198]$} & {$[0.00203]$} \\
\hline \multirow[t]{2}{*}{ Potential exp. in home country ${ }^{2}$} & $-0.000171^{\star \star \star}$ & $-0.000250^{\star \star *}$ & $-0.000244^{\star \star \star}$ \\
\hline & {$[6.18 \mathrm{e}-05]$} & {$[5.76 \mathrm{e}-05]$} & {$[5.94 \mathrm{e}-05]$} \\
\hline \multirow[t]{2}{*}{ Labour exp. in home country } & $0.0394^{\star *}$ & $0.0380^{\star \star}$ & $0.0329^{\star *}$ \\
\hline & [0.0163] & {$[0.0158]$} & {$[0.0164]$} \\
\hline \multirow[t]{2}{*}{ Heckman's lambda } & $0.0636^{\star \star}$ & $0.0775^{\star \star \star}$ & $0.0743^{\star \star \star}$ \\
\hline & [0.0291] & {$[0.0252]$} & {$[0.0260]$} \\
\hline Number of observations & 3,606 & 3,884 & 3,598 \\
\hline Adjusted $R^{2}$ & 0.194 & 0.224 & 0.236 \\
\hline
\end{tabular}

Notes: OLS estimates with controls related to gender, civil status, geographical area of birth and the region of residence. ${ }^{* * *}$, ${ }^{* *}$ and ${ }^{*}$ indicate that the estimated coefficient is statistically different from zero at $1 \%, 5 \%$, and $10 \%$ significance levels, respectively. 